ISSN 0258-7122

Bangladesh J. Agril. Res. 34(1) : 59-65, March 2009

\title{
COLLECTION, IDENTIFICATION AND BIOCHEMICAL ANALYSES OF DIFFERENT SEA WEEDS FROM SAINT MARTIN'S ISLAND
}

\author{
K.M. FormuZUl Haque ${ }^{1}$, Shamima Yesmin $\mathrm{CHY}^{2}$, SHAHINA AKTER ${ }^{3}$, \\ MD. ABDUL WAHAB ${ }^{4}$, K.K. NATH ${ }^{5}$
}

\begin{abstract}
Five species of marine algae were collected from Saint Martin's island, identified and biochemical analyses were carried out in BCSIR Laboratories, Chittagong. Biochemical composition were analysed to evaluate its food value and also to find out variation in composition during the period of investigation. The protein content of Sargassum coriifolium was $16.07 \%$, whereas in Padina Itenuis that was estimated at $8.32 \%$. The percentage of fat in Sargassuni coriitolium along with the other sea weeds was $0.5 \%$. It was found that major of the biochemical parameters of these sea weeds were higher except the protein contents than that of Spirulina. The carbohydrate content in Dictyota dichotoma (38.94\%) was lower among these sea weeds, but more than that of Spirulina. Carbohydrate contents were higher (56.29\%) in Hypnea musciformis. Mineral contents as well as other parameters, especially carbohydrate contents were higher in these algae than that of Spirulina.
\end{abstract}

Key Words: Collection, identification, biochemical analyses, sea weeds.

\section{Introduction}

Many kinds of sea weeds are edible and have entered as marine vegetables into the diets of human beings from ancient time. Scientists of the world are focusing their sight tovards the vast ocean as well as algae that is full of exploitable resources. The entire southern coast of about 300 miles of Bangladesh is exposed to the Bay of Bengal, but the vegetation of sea weeds in this area is very poor whereas it is abundant around the tiny island known as Saint Martin's Island, situated in the Bay of Bengal about 8 miles off the main land (Islam, 1970).

There are about 8,000 species of sea weeds along the world's coast live and they may extend as deep as $270 \mathrm{~m}$ (Luning, 1990). A total of 25 species of green sea weeds, 90 species of brown and 350 species of red sea weeds are found in the world sea area that are commercially important because of their protein, amino acids and mineral contents (Santhanam et al., 1980). Different species of sea weeds especially protein rich sea weeds are used as human food in different countries all over the world.

${ }^{1}$ Director-in-charge, IFST, BCSIR, Dhaka, ${ }^{2}$ Research Fellow, BCSIR Laboratories, Chittagong, ${ }^{3}$ Scientific Officer, BCSIR Laboratories, Dhaka, ${ }^{4 \& 5}$ Principle Scientific Officer, BCSIR Laboratories, Chittagong, Bangladesh. 
There are about 77 genera and 165 species of marine algae in Bangladesh, which have been reported as Cholorophyta, Chrysophyta, Phaeophyta, Rodophyta and Cyanophyta. These are available in Saint Martin's Island and Coxe's Bazar. Saint Martin is an ideal coral island of Bangladesh harboring many algal species of economic importance, which is, situated in the Northeastern part of the Bay of Bengal, between $92^{\circ} 21^{\prime} \mathrm{E}$ and $20^{\circ} 34^{\prime} \mathrm{N}$ and $20^{\circ} 38^{\prime} \mathrm{N}$ and is about 8 miles south of Badarmokam, the southern-most point of Teknaf (Islam, 1976).

Algae are important in nature and in human life as sources of food for man and animals. They are the source of iodine, potassium, magnesium, calcium. sodium, iron and vitamins and important sources of medicine and fertilizer. Industrially many important items, such as agar-agar and gelatinous material for bacteriological culture, soups, deserts, shoe polishes. cosmetics, shaving cream and laxatives are obtained from algae. In Saint Martin's Island, there is abundant growth of green, brown, and red algae almost without any proper use. There is a fresh water algae, named Spirulina has been popular due to its high nutritional value. Spirulina is being developed as the "food of the future" because of its amazing ability to synthesize high-quality concentrated food more efficiently than any other algae. Most notably, Spirulina is 65 to 71 percent complete protein, with all essential amino acids in perfect balance (Source: Applied Botany Section, Biological Research Division. BCSIR, Dhaka). In comparison, beef has only 22 percent protein.

Considering the importance of sea weeds, it can be said that, sea weeds can play a vital role in various aspects compared to other aquatic resources of Bangladesh. Much attention should he given on sea weed to compensate the food problem to some extent and fulfill the deficiency of nutrition for erecting the economy of Bangladesh. The present study can be the future directions on the detailed study of specific sea weed.

\section{Materials and Method}

Collections of sea weeds: Thirteen species of eight genera sea weeds have been collected from St. Martin's Island. They belong to genera Hypnea (white and red), Sargussum Pudinu, Liagora, Dictyota, Caulerpa, Merismopedia, Hydroclathru. The sea weeds were collected from exposed rock surfaces of the St. Martin's Island during the lowest low tide. Some drifted species were also collected from sea shore. For better accuracy, a sharp knife was used in collection of the species. The specimens were temporarily stored in plastic bags before sorting and preservation; collected specimens were washed with clean sea water to remove debris and other foreign materials. 
Identification and preservation of sea weeds: Islam (1976), Chapman (1973), Islam and Aziz (1987), Sterrer (1986) were consulted for the identification of the collected specimens. Coloured photographs were taken of the specimens.

The collected specimens were preserved by $4 \%$ formalin solution (Trono, 1988) in plastic containers for laboratory test at BCSIR Laboratory, Chittagong. Herbarium specimen were prepared from the preserved specimen and were kept in the Laboratory. Besides, a suitable amount of fresh samples were sun-dried after thorough washing in sea water and at the same time samples were used for extraction of phycocolloid.

Analysis: Biochemical analyses of Hypnea (white and red form), Sargassum, Pudina diclyota were carried out in the BCSIR Laboratories, Chittagong. The analyses include percentage of protein, moisture, ash, fats, carbohydrates, and minerals (calcium, magnesium, sodium, potassium, iron) of the sea weeds. Fresh sun-dried samples have been taken for biochemical analysis. Protein was determined by Kjeldahl method, fat was extracted with low boiling petroleum ether, by sox-let extraction and the extract thus obtained was weighed after careful recovery of the solvent. Moisture content was determined by complete drying of the sample at $100 \pm 5^{\circ} \mathrm{C}$ i.e., by complete removal of free water present in the sample. The loss in weight of the sample is the measure of moisture content. The ash content of the sample is the inorganic residue left after complete removal of the organic residue by muffling at about $550-650^{\circ} \mathrm{C}$ in the muffle furnace. Most of the chemical constants were determined according to the standard procedure of AOCS (AOAC, 1990).

Carbohydrate was quantified by following standard method (Winton and Winton, 1947). For the determination of Calcium, Magnasium, Sodium, Potassium, and Iron, the ash samples were first digested in I M HC1 and the concentration curves of the standard elements adapting titrimetric, spectrophotometric and flame photometric methods (Jefferx. 1979).

\section{Results and Discussion}

\section{Collection and identification of the samples}

The sea weeds were identified as Hypnea musciformis, Hypnea pannosa, Sargassum coriifolium, Padina tenuis and Dictyota dichotoma according to Islam (1976) and Chapman (1973).

Hlypnea muscjformis: Plant bushy, upto $45 \mathrm{~cm}$ long spreading slender branches, often with spineless branchlets and cozier tip or incused, off white in colour (Fig. a).

Hypnea parnwsa: Plant bushy, upto $40 \mathrm{~cm}$ long spreading slender branches, often with spineless branchlets and cozier tip or incused, redish in colour ((Fig. b). 
Padina tenuis: Plants dark, $8-10 \mathrm{~cm}$ in height, $2-4 \mathrm{~cm}$ breadth and basal portion forming a rhizoidous disc continuing into a narrow stripe which expands upwards becoming fan- shaped and dichotomously divided lateral margins of the fronds entire (Fig. c).
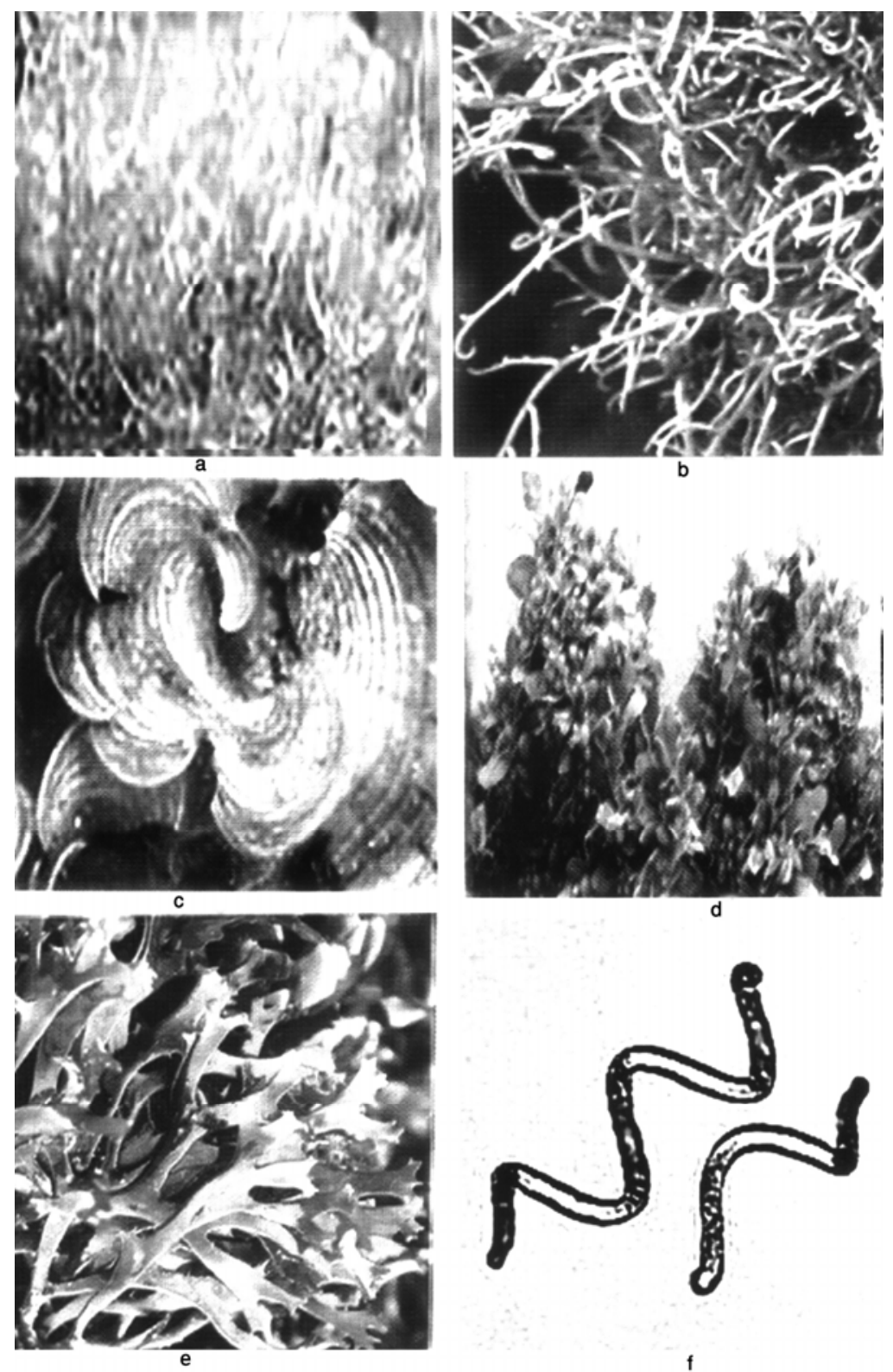

Fig. a-e: Different sea weeds from Sint Maritn's Island, (a) Hypnea musciformis, (b) $H$. pannosa, (c) Padina tenuis, (d) Sargassum corifolium and (e) Dictota dichotoma. (f) Spirulina sp. 
Sargassum corijfolium: Plants large with a basal holdfast, upper portion bushy, branched receptacles, leaves of the lower portions of the plant larger than those of the upper, simple or divided (Fig. d).

Dictyota dichotoma: Plants $15-20 \mathrm{~cm}$ in height, yellow brown with a thick basal disc forming the holdfast, upper portion repeatedly dichotomously branched, angles between branches wide apices equal rarely slightly unequal. broadly rounded, sometimes acute (Fig. e).

\section{Biochemical analyses of the sea weeds}

Proximate biochemical composition, such as protein, fat, carbohydrate, fibre, minerals, moisture and ash were determined from different sea weeds, namely Hypnea musciformis, H. pannosa, Sargassum coriifolium, Padina tenuis and Dictyota dichotoma of Saint Martin's Island (Table $1 \& 2$ ).

Bird and Benson (1987) recorded the mean protein levels in Sargassum petropleuron and S. filipendula, which were $5.6 \%$ and $5.7 \%$, respectively. In the present investigation, Sargassum coriifolium has the highest percentage of protein (16.07\%) among the species, while lowest in Padina tenuis, which was estimated as $8.32 \%$ (Table 1 ). In the present investigation, the moisture contents of sea weeds were found higher (15\%) in Hypnea musciformis and lower (10\%) in Dictyotu dichotoma. The ash contents in Hypnea musciförmis were lower (11 $\%$ ) and higher (3 6\%) in Padina tenuis (Table 1).

Bird and Benson (1987) recorded fat levels in Surgassum pteropleuron, which ranged from 0.6 to $2.7 \%$ and in S. filipendula, it was 1.0 to $3.3 \%$. The mean values of fat in these species were recorded as $1.4 \%$ and $2.2 \%$, respectively. In this investigation, the percentage of fat in all the species were similar in 0.5\% which does not agree with the results of Bird and Benson (1987). The fibre content was higher (8.5\%) in Hypnea pannosa followed by Dictyota dichotoma, whereas it was much lower (2.5\%) in case of Padina tenuis (Table 1).

In the present study, the carbohydrate and mineral contents of the locally popular sea weeds (Spirulina) were also analyzed for comparison (Source: wvvw.Spirulina.source.com. Applied Botany Section, Biological Research Division, BCSIR, Dhaka). After this investigation, it was found that the biochemical parameters of these sea weeds were higher than that of Spirulina except the protein contents. In these sea weeds, the protein contents ranged from 8.32 to $16.07 \%$, whereas in Spirulina, it was $55-65 \%$. But in respect of Carbohydrate, these sea weeds were more rich than that of Spirulina. Carbohydrate content was lower (38.94\%) in Dictyota dichotoma, but higher $(56.29 \%)$ in Hypnea musciformis (Table 1). Whereas, in Spirulina sp. it was only $10-20 \%$. So, Hypneu sp. were rich in carbohydrate as compared to other species. 
Table 1. Proximate biochemical composition (\%) of five genera of sea weeds in Saint Martin's Island.

\begin{tabular}{lll|l|l|l|c}
\hline \multicolumn{1}{c}{ Name of the sps. } & Protein & Carbohydrates & Fats & Fibre & Moisture & Ash \\
\hline $\begin{array}{l}\text { Hypnea musciformis } \\
\text { (after washing) }\end{array}$ & 12.21 & 5629 & & & & \\
$\begin{array}{l}\text { Hypnea musciformis } \\
\text { (without wash) }\end{array}$ & & 55.29 & 0.5 & 5.0 & 15 & 11 \\
Hvpnea pannosa & 11.12 & 48.88 & & & 12 & 15 \\
Padina tenuis & 8.32 & 41.68 & 0.5 & 8.5 & 13 & 15 \\
Sargassuni coriifolium & 16.07 & 47.43 & 0.5 & 2.5 & 11 & 36 \\
Dictyota dichotoma & 15.56 & 38.94 & 0.5 & 6.5 & 11 & 19 \\
& & & 0.5 & 8.0 & 10 & 27 \\
Spirulina sp. & 55.65 & 10.20 & - & --- & 7 & --- \\
\end{tabular}

*Source: Applied Botany Section, Biological Research Division, BCSIR, Dhaka.

Table 2. Mineral contents (mg/g) of five genera of sea weeds in Saint Martin's Island.

\begin{tabular}{l|c|c|c|c|c}
\hline \multicolumn{1}{c|}{ Name of the sps. } & $\mathrm{Ca}$ & $\mathrm{Mg}$ & $\mathrm{Na}$ & $\mathrm{K}$ & $\mathrm{Fe}$ \\
\hline 1.a Hvpnea musciformis (after washing) & 10.21 & 12.64 & 15.00 & 10,00 & 1,24 \\
1.b Hypnea musciformis (without wash) & 11.66 & 15.63 & 35.71 & 10.99 & 3.87 \\
2. Hypneapannosa & 20.02 & 39.91 & 127.65 & 31.91 & 2.95 \\
3. Padina lenuis & 48.00 & 44.13 & 55.00 & 30.00 & 6.64 \\
4. Surgassum coriifolium & 15.86 & 15.45 & 59.78 & 10.86 & 1.90 \\
5. Dyctyota dichotoma & 4.55 & 17.17 & 56.82 & 5.68 & 3.64 \\
6. Spirulina sp. & 4.00 & 4.80 & 7.30 & 15.2 & 1.60 \\
\hline
\end{tabular}

*Source: Applied Botany Section, Biological Research Division, BCSIR, Dhaka.

All the minerals, such as calcium, magnesium, sodium, potassium, and iron were higher in Hyppnea musciformis, H. pannosa, Padina tenuis, Sargassum coriifolium and Dictyota dichotoma than that of Spirulina. In Padina sp., calcium and magnesium contents per g were high, 48.00 and $44.13 \mathrm{mg}$, respectively. Whereas, in Spirulina, calcium, and magnesium contents per gram were recorded 4.00 and $4.80 \mathrm{mg}$, respectively. Even, the lowest contents of $\mathrm{Ca}$ and $\mathrm{Mg}$ in Dictyota dichotoma (4.55 $\mathrm{mg}$ ) and in Hypnea musciformis (12.64 mg) were higher than that of Spirulina. Sodium contents were much higher $(127.65 \mathrm{mg})$ in Hypneu pannosa than that of Spirulina $(7.3 \mathrm{mg})$ and other species. The potassium contents were $15.2 \mathrm{mg}$ per gram in Spirulina whereas, Hypnea pannosa and Padina tenuis contained 31.91 and $30.00 \mathrm{mg}$ of $\mathrm{K}$. Iron contents were also higher in Padina tenuis containing $6.64 \mathrm{mg} / \mathrm{g}$ whereas, in Spirulina, it was recorded 1.6 $\mathrm{mg} / \mathrm{g}$ (Table 2). 
Now-a-days sea weeds have been widely accepted by the people of coastal region throughout the world due to their important sources of nutrients. Especially Padina lenuis and Hypnea spp. are usually eaten whole plants as a good source of minerals. In Hypneu pannosa Na contents (127.65) were much higher, but $\mathrm{Ca}, \mathrm{Mg}$, and $\mathrm{Fe}$ were higher in Padina tenuis, which was 48.00, 44.13, and $6.64 \mathrm{mg} / \mathrm{g}$, respectively (Table 2). Though protein contents of these sea weeds were less, but carbohydrate and mineral contents were higher. These sea weeds may solve the problems of carbohydrate and mineral deficiency in human nutrition by consuming these sea weeds in near future. Sea weeds as well as red and brown algae have the ability to accumulate iodine and thus they may be regarded as a good source of concentrated iodine.

\section{References}

AOAC. 1990. In official methods and recommended practice of the AOCS 4th Ed. AOCS. Champaign. IL. USA. AOCS official method Ce. pp.1 I-89.

Bird, K.T. and P.H. Benson (Eds). 1987. Sea weeds cultivation for renewable, development in aquaculture and fisheries Sciences 16, Elsevier. $381 \mathrm{p}$.

Chapman, J.V. 1973. Sea weeds and Their Uses, Methuer and Co. Ltd. 299p.

Islam, A.K.M.N. 1970. Preliminary Ecological Report on the Marine Algal Flora of the St. Martin's Island. East Pakistan. J. Asiatic Soc., Pakistan. 15(3): 283.

Islam, A.K.M.N. 1976. Contribution to the study of Banthic Marine algae of Bangladesh. Bibliotheca Phycologica. 19:253.

Islam. A.K.M.N. and A. Aziz. 1987. Addition to the List of Marine Algae of St. Martin's Island, Bangladesh, II. Red and Blue Green Algae. Nova Hedwigia 36:657p.

Jefferx, G.N., J. Basett, J. Mendham and R.C. Denny. 1979. Vogel's Textbook of Quantitative Chemical Analysis, 5th Edition, Addison Wesley Longman Inc.

Luning, K. 1990. Sea weeds, their Environment, Biogeography and Ecophysiology. Willey lnterscience Publication. pp.3-370.

Sterrer, W. 1986. Marine Fauna and Flora of Bermuda. A systematic guide to organisms. John Wiley \& Sons. New York pp. 26-66.

Santhanam, R.N., Remananthan and G. Jagathusan. 1990. Coastal Aquaculture in India. C.B.S. Publishers and Distributors. pp. 159-162.

Trono, G.C. JR. 1988. Philippines Sea weeds, National Book Store Inc., 32lp.

Winton, A.L. and K.B., Winton. 1947. The Analysis of Foods, John Willey and Sons Inc.. London. 